\title{
HUBUNGAN TINGKAT KEJADIAN DIABETES MELITUS TERHADAP KONDISI HIPERTENSI DI INDONESIA
}

\author{
I Putu Agus Dharma Hita ${ }^{1}$, Doni Pranata² \\ ${ }^{1}$ Universitas Triatma Mulya, Pendidikan Olah Raga Kesehatan dan Rekreasi, Bali, Indonesia \\ ${ }^{2}$ Universitas Negeri Yogyakarta, IImu Keolahragaan, Yogyakarta, Indonesia \\ putuagusdharma@yahoo.com ,dpranata9710@gmail.com
}

\begin{abstract}
Diabetes mellitus and hypertension are one of the many diseases that are very dangerous to the health of the body, even diseases that have a high mortality rate. This study aims to determine the relationship between the incidence of diabetes mellitus and hypertension in Indonesia. This type of research is a type of correlational research using a simple regression technique with the help of the SPSS 22 application for Windows. The data used in this study is the 2018 National Basic Health Research Report. The data collection method was carried out through interviews, measurements, and examinations. The sample in this study were all citizens of the Republic of Indonesia in 2018 who experienced diabetes mellitus and hypertension conditions. The results of this study are that there is a relationship between the incidence of diabetes mellitus and hypertension conditions in Indonesia in 2018 with a relationship rate of $56.4 \%$.
\end{abstract}

Keywords: diabetes mellitus, hypertension, Indonesia

\begin{abstract}
Abstrak
Penyakit diabetes melitus dan hipertensi merupakan satu dari sekian banyak penyakit yang sangat membahayakan bagi kesehatan tubuh, bahkan merupakan penyakit yang memiliki nilai kematian yang tinggi. Penelitian ini bertujuan untuk mengetahui hubungan tingkat kejadian diabetes melitus terhadap kondisi hipertensi di Indonesia. Jenis penelitian ini merupakan jenis penelitian korelasional dengan menggunakan teknik regresi sederhana dengan bantuan aplikasi SPSS 22 for Windows. Data yang digunakan dalam penelitian ini yaitu data Laporan Nasional Riset Kesehatan Dasar tahun 2018, Metode pengumpulan data tersebut dilakukan melalui wawancara, pengukuran, dan pemeriksaan. Sampel dalam penelitian ini adalah seluruh warga negara Republik Indonesia pada tahun 2018 yang mengalami kondisi diabetes melitus dan kondisi hipertensi. Hasil penelitian ini adalah terdapat hubungan tingkat kejadian diabetes melitus terhadap kondisi hipertensi di Indonesia pada tahun 2018 dengan tingkat hubungan sebesar $56,4 \%$.
\end{abstract}

Kata Kunci: diabetes melitus, hipertensi, Indonesia

\section{PENDAHULUAN}

Indonesia merupakan sebuah negara kepulauan yang mempunyai sebaran penduduk terbanyak ke 4 di dunia, di tahun 2019 jumlah penduduk indonesia tercatat 268.074.600 (https://www.bps.go.id/). Dengan begitu banyaknya sebaran penduduk yang begitu merata tentunya mempunyai banyak ragam budaya, bahasa, maupun makanan. Dalam bidang pendidikan, Berdasarkan survey yang dilakukan oleh Programme for International Student Assessment Indonesia tergolong menempati peringkat 72 
JURNAL SPORTA SAINTIKA

P-ISSN 2505-5651

E-ISSN 2579-5910

dari 77, banyak warga negara indonesia yang belum menerima pendidikan yang merata (PISA, 2019). Berdasarkan survey yang dilakukan oleh Programme for International Student Assessment (PISA, 2019) menunjukan bahwa mayoritas penduduk Indonesia hanya menempuh Sekolah Menengah Pertama (SMP). Pada dasarnya banyak yang diharapkan ketika banyak masyarkat di indonesia menempuh pendidikan setinggi-tinginya karena melalui pendidikan diharapkan dapat memberikan implikasi terhadap kontribusi pemikiran yang membawa indonesia ke lebih baik. Selain itu melalui pendidikan diharapkan mampu mengedukasi kepada dirinya sendiri, masyarakat kelompok kecil maupun masyarakat luas.

Pola hidup sehat merupakan suatu cara yang begitu kompleks untuk mencegah munculnya berbagai penyakit. Kesehatan merupakan investasi, artinya apa yang kita lakukan dan konsumsi hari ini dapat memberikan dampak terhadap kesehatan kita di masa yang akan datang. Oleh karena itu, untuk menerapkan kebiasaan tersebut memerlukan pemahaman yang mendalam. Yakni melalui jenjang pendidikan, prilaku kebiasaan hidup yang sehat dapat memberikan kontribusi meningkatkan tingkat harapan hidup masyarakat.

Ketika masyakarat di negara Indonesia memiliki taraf kehidupan yang sehat, maka dapat memberikan implikasi juga terhadap etos kerja yang maksimal. Hal ini terefleksi pada pendapat yang dikemukakan oleh (Pane et al., 2020) Pola prilaku hidup sehat dilakukan dengan cara memperhatikan pola makan, karena melalui makanan yang masuk ke dalam tubuh manusia dapat mempengaruhi kinerja organ yang ada di dalam tubuh, apabila asupan yang dikonsumsi sehat dan mengandung gizi yang seimbang maka dapat membuat organ yang ada didalam tubuh bekerja secara maksimal dan memperpanjang usia organ tersebut.

Pola prilaku hidup sehat juga dapat menghindarkan dari berbagai macam penyakit baik penyakit menular maupun tidak menular. Penyakit menular merupakan sebuah penyakit yang disebabkan oleh agen bilogi seperti virus, bakteri, atau parasit bukan disebabkan oleh faktor fisik seperti luka bakar atau kimia (Sumampouw, 2017) sedangkan penyakit tidak menular (PTM) merupakan penyakit yang tidak ditularkan dan tidak ditransmisikan kepada orang lain dengan bentuk kontak apapun , melalui penyuluhan dan pengetahuan masyarakat mengenai penerapan pola hidup sehat. Masyarakat diharapkan dapat mengajak serta menerapakan pengetahuan tersebut untuk mencegah berbagai penyakit, penyakit tidak menular banyak dijumpai di masyarakat, faktor hereditas (keturunan) merupakan faktor utama penyebaran penyakit tersebut. Penyakit tersebut dapat dicegah apabila individu menyadari sejak dini kondisi keturunan serta penyakit yang ada di keluarganya.

Survey yang telah dilakukan di indonesia, menunjukan bahwa indonesia, masuk ke dalam peringkat 6 angka kejadian diabetes melitus terbanyak di dunia dengan berbagai peliknya penyakit 
JURNAL SPORTA SAINTIKA

P-ISSN 2505-5651

E-ISSN 2579-5910

yang ada di indonesia (Betteng, 2014), tentunya banyak faktor yang melatar belakangi penyakit tersebut, faktor yang paling utama adalah banyak masyarakat di Indonesia tidak menerpakan budaya hidup sehat. Dengan memperhatikan pola makan maupun aktivitas gerak sehari-hari. Diabetes merupakan salah satu penyumbang penyakit yang muncul di tengah masyarakat.

Diabetes merupakan penyakit komplikasi, artinya sebagai pemicu timbulnya penyakit lain. Hal ini senada dengan pendapat DM merupakan penyakit yang ditandai oleh meningkatnya kadar gula darah yang lebih tinggi dari batas normal yang terjadi karena kelainan sekresi insulin, kerja insulin atau keduanya sehingga memerlukan upaya penanganan yang tepat dan serius (Pratita, 2013). Pendapat tersebut didukung oleh Nugroho (2018) menyampaikan bahwa Diabetes Mellitus (DM) merupakan suatu penyakit yang melibatkan hormon endokrin pankreas, antara lain insulin dan glukagon. Manifestasi utamanya mencakup gangguan metabolisme lipid, karbohidrat, dan protein yang pada gilirannya merangsang kondisi hiperglikemia. Indonesia merupakan salah satu dari 10 besar negara dengan jumlah penderita diabetes terbanyak.berdasarkan hasil (Riskesdas, 2018) kasus diabetes melitus di Indonesia berdasrkan diagnosis dokter pada umur > 15 Tahun sebesar $2 \%$. Angka ini menunjuka peningkatan dibandingkan prevalensi diabetes melitus pada penduduk $>15$ tahun pada hasil rikesdas 2013 sebesar $1.5 \%$.

Diabetes terbagi menjadi 2 jenis, yakni DM tipe 1 dan DM tipe 2 (Nindyasari, 2010). Merujuk pada pendapat yang dikemukakan oleh (Setiawan et al., 2018) Ada banyak faktor yang memicu terjadinya diabetes melitus. Semakin cepat kondisi diabetes melitus diketahui dan ditangani akan mencegah komplikasi yang terjadi. Faktor faktor yang di anggap sebagai penyebab diabetes melitus antara lain kelainan sel beta pankreas, berkisar dari hilangya sel beta sampai kegagalan sel beta melepas insulin. Selain faktor lainnya antara lain adanya infeksi, pola diet yang tidak sehat,umur, obesitas, kegemukan,kehamilan, gangguan sistem imunitas serta kelainan insulin (Thompson \& Bhushan, 2017). Seseorang dikatakan menderita diabetes apabila pada pemeriksaan darah dari pembuluh darah halus (kapiler) glukosa darah lebih dari $120 \mathrm{mg} / \mathrm{dL}$ pada keadaan puasa dan/atau lebih dari 200 $\mathrm{mg} / \mathrm{dL}$ untuk 2 jam setelah makan. Bila yang diambil darah dari pembuluh balik (vena) maka kadar glukosa puasa lebih dari $140 \mathrm{mg} / \mathrm{dL}$ dan/atau $200 \mathrm{mg} / \mathrm{dL}$ untuk 2 jam setelah makan. Glukosa darah yang kurang dari 120 atau $140 \mathrm{mg} / \mathrm{dL}$ pada keadaan puasa namun antara 140-200 mg/dL pada 2 jam setelah makan disebut sebagai Toleransi Glukosa Terganggu (TGT) yang tidak memerlukan pengobatan tapi tetap memerlukan pemantauan secara berkala (Fransisca, 2018).

Penyakit diabetes memiliki pengaruh terhadap munculnya beberapa penyakit lain, hal ini dikarenakan kadar gula dalam darah relatif tinggi yang menyebabkan hubungan secara tidak langsung munculnya penyakit hipertensi (Saragih, 2018). Diabetes merupakan salah satu penyakit 
JURNAL SPORTA SAINTIKA

P-ISSN 2505-5651

E-ISSN 2579-5910

yang prevalensinya cukup tinggi akibat pola makan yang tidak seimbang dan pola hidup tidak sehat (Yosmar et al., 2018). lingkar pinggang berpengaruh secara signifikan dengan penyakit diabetes dan kategori lingkar pinggang yang memiliki peluang paling besar terkena penyakit diabetes melitus tipe 2 adalah lingkar pinggang laki-laki yang lebih besar dari $102 \mathrm{~cm}$ atau perempuan yang lebih besar dari $88 \mathrm{~cm}$ (Trisnawati, 2018).

Hipertensi merupakan penyakit yang berkaitan dengan tekanan darah sesorang, dimana tekanan darahnya berada di posisi diatas orang bertekanan darah normal. Faktor penyebab timbulnya penyakit hipertensi menurut (Suoth et al., 2014) Penyakit hipertensi sangat dipengaruhi oleh Gaya hidup yang tidak sehat. Ada beberapa hal yang menyebabkan terjadinya penyakit hipertensi, diantaranya mengkonsumsi makanan, tidak melakukan aktifitas fisik serta tidak berolahraga secara teratur, tidak dapat mengendalikan stres dan adanya kebiasaan merokok. Banyak pasien yang mengalami penyakit hipertensi yang juga mengalami penyakit komplikasi lain, diantaranya adalah penyakit diabetes melitus. Berdasarkan latar belakang yang telah disampaikan diatas, penelitian ini bertujuan untuk melihat bagaimana kemungkinan tingkat kejadian pasien yang mengalami penyakit diabetes melitus terhadap penyakit hipertensi.

\section{METODELOGI PENELITIAN}

Penelitian ini bertujuan untuk mengetahui hubungan tingkat kejadian diabetes melitus terhadap kondisi hipertensi di Indonesia. Jenis penelitian ini merupakan jenis penelitian korelasional dengan menggunakan teknik regresi sederhana dengan bantuan aplikasi SPSS 22 for Windows dengan taraf signifikan $5 \%(p<0,05)$. Data yang digunakan dalam penelitian ini adalah data Laporan Nasional Riset Kesehatan Dasar Tahun 2018 yang tersedia pada Web Site Badan Penelitian dan Pengembangan Kesehatan (Litbangkes) Kementerian Kesehatan Republik Indonesia https://www.litbang.kemkes.go.id/laporan-riset-kesehatan-dasar-riskesdas/. Sampel dalam data tersebut adalah seluruh warna negara Republik Indonesia pada tahun 2018. Data yang terkumpul adalah data tingkat persentase kejadian diabetes melitus dan hipertensi pada semua provinsi yang ada di Indonesia yang termuat dalam Laporan Nasional Riskesdas Kemenkes 2018 (Kemenkes, 2018). Data Riskesdas tahun 2018 dikumpulkan oleh tenaga pengumpul data berlatar belakang pendidikan minimal Diploma 3 kesehatan. Metode pengumpulan data dilakukan melalui wawancara, pengukuran, dan pemeriksaan. Riskesdas merupakan survei berskala nasional dengan desain potong lintang (cross-sectional) dan non-intervensi.

\section{HASIL PENELITIAN}

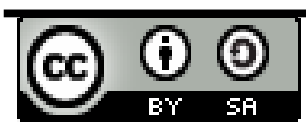


JURNAL SPORTA SAINTIKA

P-ISSN 2505-5651

E-ISSN 2579-5910

Berikut disajikan mengenai karakteristik sampel diabetes melitus pada tabel 1 sebagai berikut:

Tabel 1. Karakteristik Sampel Diabetes Melitus di Indonesia Tahun 2018

\begin{tabular}{|c|c|}
\hline Karakteristik Sampel & $\mathbf{N}$ (Jumlah) \\
\hline \multicolumn{2}{|c|}{ Kelompok Umur } \\
\hline$<1$ & 18.225 \\
\hline $1-4$ & 73.188 \\
\hline $5-14$ & 182.338 \\
\hline $15-24$ & 165.644 \\
\hline $25-34$ & 159.708 \\
\hline $35-44$ & 151.539 \\
\hline $45-54$ & 124.652 \\
\hline $55-64$ & 83.251 \\
\hline $65-74$ & 40.180 \\
\hline $75+$ & 18.565 \\
\hline \multicolumn{2}{|l|}{ Jenis Kelamin } \\
\hline Laki - Laki & 510.714 \\
\hline Perempuan & 506.576 \\
\hline \multicolumn{2}{|l|}{ Pendidikan } \\
\hline Tidak/Belum Pernah Sekolah & 70.895 \\
\hline Tidak Tamat SD/MI & 181.429 \\
\hline Tamat SD/MI & 215.967 \\
\hline Tamat SLTP/MTS & 160.320 \\
\hline Tamat SLTA/MA & 210.746 \\
\hline Tamat D1/D2/D3/PT & 64.093 \\
\hline \multicolumn{2}{|l|}{ Pekerjaan } \\
\hline Tidak Bekerja & 233.629 \\
\hline Sekolah & 126.626 \\
\hline PNS/TNI/Polri/BUMN/BUMD & 21.931 \\
\hline
\end{tabular}


JURNAL SPORTA SAINTIKA

P-ISSN 2505-5651

E-ISSN 2579-5910

\begin{tabular}{|l|c|} 
Pegawai Swasta & 75.781 \\
\hline Wiraswasta & 105.489 \\
\hline Petani/Buruh Tani & 133.261 \\
\hline Nelayan & 5.556 \\
\hline Buruh/Sopir/Pembantu Ruta & 75.590 \\
\hline Lainnya & 40.644 \\
\hline \multicolumn{2}{|c|}{ Tempat Tinggal } \\
\hline Perkotaan & 556.419 \\
\hline Pedesaan & 460.871 \\
\hline
\end{tabular}

Data mengenai tingkat kondisi diabetes melitus pada masing-masing provinsi yang ada di Indonesia disajikan pada tabel 2 sebagai berikut:

Tabel 2. Tingkat Kondisi Diabetes Melitus di Indonesia Tahun 2018

\begin{tabular}{|c|c|c|}
\hline \multirow{2}{*}{ Provinsi } & \multicolumn{2}{|c|}{ Diagnosis Diabetes Melitus } \\
\cline { 2 - 3 } & $\%$ & $95 \%$ Cl \\
\hline Aceh & 1,7 & $1,5-1,9$ \\
\hline Sumatera Utara & 1,4 & $1,3-1,5$ \\
\hline Sumatera Barat & 1,2 & $1,0-1,3$ \\
\hline Riau & 1,3 & $1,1-1,5$ \\
\hline Jambi & 1,0 & $0,9-1,2$ \\
\hline Sumatera Selatan & 0,9 & $0,8-1,1$ \\
\hline Bengkulu & 0,9 & $0,8-1,1$ \\
\hline Lampung & 1,0 & $0,9-1,1$ \\
\hline Bangka Belitung & 1,8 & $1,6-2,1$ \\
\hline Kepulauan Riau & 1,2 & $0,9-1,6$ \\
\hline DKI Jakarta & 2,6 & $2,3-2,9$ \\
\hline Jawa Barat & 1,3 & $1,2-1,4$ \\
\hline Jawa Tengah & 1,6 & $1,5-1,7$ \\
\hline DI Yogyakarta & 2,4 & $2,1-2,8$ \\
\hline Jawa Timur & 2,0 & $1,9-2,1$ \\
\hline
\end{tabular}


JURNAL SPORTA SAINTIKA

P-ISSN 2505-5651

E-ISSN 2579-5910

\begin{tabular}{|c|c|c|}
\hline Banten & 1,6 & $1,4-1,8$ \\
\hline Bali & 1,3 & $1,1-1,5$ \\
\hline Nusa Tenggara Barat & 1,2 & $1,0-1,3$ \\
\hline Nusa Tenggara Timur & 0,6 & $0,5-0,7$ \\
\hline Kalimantan Barat & 1,1 & $1,0-1,3$ \\
\hline Kalimantan Tengah & 1,1 & $1,0-1,3$ \\
\hline Kalimantan Selatan & 1,3 & $1,1-1,5$ \\
\hline Kalimantan Timur & 2,3 & $2,0-2,6$ \\
\hline Kalimantan Utara & 1,6 & $1,3-2,0$ \\
\hline Sulawesi Utara & 2,3 & $2,0-2,5$ \\
\hline Sulawesi Tengah & 1,5 & $1,3-1,8$ \\
\hline Sulawesi Selatan & 1,3 & $1,2-1,5$ \\
\hline Sulawesi Tenggara & 0,9 & $0,7-1,0$ \\
\hline Gorontalo & 1,7 & $1,5-2,1$ \\
\hline Sulawesi Barat & 0,9 & $0,6-1,1$ \\
\hline Maluku & 0,7 & $0,6-1,0$ \\
\hline Maluku Utara & 1,0 & $0,8-1,2$ \\
\hline Papua Barat & 1,3 & $1,0-1,7$ \\
\hline Papua & 0,8 & $0,6-0,9$ \\
\hline INDONESIA & 1,5 & $1,5-1,5$ \\
\hline
\end{tabular}

Sumber: Riskesdas Kemenkes 2018

Berdasarkan hasil data dari (Kemenkes, 2018) mengenai tingkat kondisi diabetes melitus pada masing-masing provinsi diatas, dapat dilihat provinsi tertinggi yang memiliki tingkat kejadian diabetes melitus adalah Provinsi DKI Jakarta dengan angka 2,6\% dan provinsi yang memiliki tingkat kejadian diabetes melitus terendah adalah Provinsi Nusa Tengga Timur dengan angka 0,6\%.

Berikut disajikan mengenai karakteristik sampel hipertensi pada tabel 3 sebagai berikut:

Tabel 3. Karakteristik Sampel Hipertensi di Indonesia Tahun 2018

\begin{tabular}{|c|c|}
\hline Karakteristik Sampel & N (Jumlah) \\
\hline \multicolumn{2}{|c|}{ Kelompok Umur } \\
\hline
\end{tabular}


JURNAL SPORTA SAINTIKA

P-ISSN 2505-5651

E-ISSN 2579-5910

\begin{tabular}{|c|c|}
\hline $18-24$ & 106.849 \\
\hline $25-34$ & 152.373 \\
\hline $35-44$ & 144.578 \\
\hline $45-54$ & 118.927 \\
\hline $55-64$ & 79.427 \\
\hline $65-74$ & 38.335 \\
\hline $75+$ & 17.712 \\
\hline \multicolumn{2}{|l|}{ Jenis Kelamin } \\
\hline Laki - Laki & 327.150 \\
\hline Perempuan & 331.051 \\
\hline \multicolumn{2}{|l|}{ Pendidikan } \\
\hline Tidak/Belum Pernah Sekolah & 39.556 \\
\hline Tidak Tamat SD/MI & 80.199 \\
\hline Tamat SD/MI & 159.357 \\
\hline Tamat SLTP/MTS & 119.569 \\
\hline Tamat SLTA/MA & 198.150 \\
\hline Tamat D1/D2/D3/PT & 61.371 \\
\hline \multicolumn{2}{|l|}{ Pekerjaan } \\
\hline Tidak Bekerja & 196.220 \\
\hline Sekolah & 21.093 \\
\hline PNS/TNI/Polri/BUMN/BUMD & 21.228 \\
\hline Pegawai Swasta & 72.970 \\
\hline Wiraswasta & 101.834 \\
\hline Petani/Buruh Tani & 128.377 \\
\hline Nelayan & 5.259 \\
\hline Buruh/Sopir/Pembantu Ruta & 72.315 \\
\hline Lainnya & 38.905 \\
\hline \multicolumn{2}{|c|}{ Tempat Tinggal } \\
\hline Perkotaan & 364.630 \\
\hline Pedesaan & 293.571 \\
\hline
\end{tabular}


JURNAL SPORTA SAINTIKA

P-ISSN 2505-5651

E-ISSN 2579-5910

Data mengenai tingkat kondisi hipertensi pada masing-masing provinsi yang ada di Indonesia disajikan pada tabel 4 sebagai berikut:

Tabel 4. Tingkat Kondisi Hipertensi di Indonesia Tahun 2018

\begin{tabular}{|c|c|c|}
\hline \multirow[b]{2}{*}{ Provinsi } & \multicolumn{2}{|c|}{ Hipertensi } \\
\hline & $\%$ & $95 \% \mathrm{Cl}$ \\
\hline Aceh & 9,32 & $8,89-9,77$ \\
\hline Sumatera Utara & 5,52 & $5,20-5,86$ \\
\hline Sumatera Barat & 7,27 & $6,83-7,73$ \\
\hline Riau & 8,44 & $7,94-8,96$ \\
\hline Jambi & 7,43 & $6,92-7,98$ \\
\hline Sumatera Selatan & 7,34 & $6,88-7,82$ \\
\hline Bengkulu & 8,36 & $7,74-9,02$ \\
\hline Lampung & 7,95 & $7,48-8,45$ \\
\hline Bangka Belitung & 8,32 & $7,63-9,05$ \\
\hline Kepulauan Riau & 8,62 & $7,69-9,66$ \\
\hline DKI Jakarta & 10,17 & $9,48-10,90$ \\
\hline Jawa Barat & 9,67 & $9,32-10,03$ \\
\hline Jawa Tengah & 8,17 & $7,90-8,44$ \\
\hline DI Yogyakarta & 10,68 & $9,93-11,49$ \\
\hline Jawa Timur & 8,01 & $7,76-8,27$ \\
\hline Banten & 8,61 & $8,07-9,17$ \\
\hline Bali & 9,57 & $8,96-10,22$ \\
\hline Nusa Tenggara Barat & 7,19 & $6,64-7,78$ \\
\hline Nusa Tenggara Timur & 5,36 & $5,01-5,74$ \\
\hline Kalimantan Barat & 8,16 & $7,62-8,72$ \\
\hline Kalimantan Tengah & 8,38 & $7,77-9,03$ \\
\hline Kalimantan Selatan & 9,98 & $9,40-10,59$ \\
\hline Kalimantan Timur & 10,57 & $9,84-11,34$ \\
\hline Kalimantan Utara & 10,46 & $9,25-11,80$ \\
\hline Sulawesi Utara & 13,21 & $12,48-13,97$ \\
\hline Sulawesi Tengah & 8,69 & $8,09-9,33$ \\
\hline
\end{tabular}


JURNAL SPORTA SAINTIKA

P-ISSN 2505-5651

E-ISSN 2579-5910

\begin{tabular}{|c|c|c|}
\hline Sulawesi Selatan & 7,22 & $6,81-7,65$ \\
\hline Sulawesi Tenggara & 6,25 & $5,71-6,84$ \\
\hline Gorontalo & 10,11 & $9,22-11,07$ \\
\hline Sulawesi Barat & 6,58 & $5,84-7,40$ \\
\hline Maluku & 5,01 & $4,41-5,68$ \\
\hline Maluku Utara & 5,71 & $4,99-6,53$ \\
\hline Papua Barat & 7,45 & $6,54-8,48$ \\
\hline Papua & 4,39 & $3,83-5,02$ \\
\hline INDONESIA & $\mathbf{8 , 3 6}$ & $\mathbf{8 , 2 6}-\mathbf{8 , 4 7}$ \\
\hline
\end{tabular}

Sumber: Riskesdas Kemenkes 2018

Berdasarkan hasil data dari (Kemenkes, 2018) mengenai tingkat kondisi hipertensi pada masing-masing provinsi diatas, dapat dilihat provinsi tertinggi yang memiliki tingkat kejadian hipertensi adalah Provinsi Sulawesi Utara dengan angka 13,21\% dan provinsi yang memiliki tingkat kejadian hipertensi terendah adalah Provinsi Papua dengan angka 4,39\%. Selanjutnya hasil dari uji korelasi menggunakan teknik regresi sederhana ditampilkan pada tabel 5 sebagai berikut:

Tabel 5. Hasil Uji Regresi Sederhana

\begin{tabular}{|c|c|c|c|c|c|}
\hline \multicolumn{7}{|c|}{ ANOVA $^{\text {a }}$} \\
\hline Model & $\begin{array}{c}\text { Sum of } \\
\text { Squares }\end{array}$ & $d f$ & $\begin{array}{c}\text { Mean } \\
\text { Square }\end{array}$ & $F$ & Sig. \\
\hline Regression & 65.461 & 1 & 65.461 & 41.386 & $.000^{\mathrm{b}}$ \\
\hline Residual & 50.615 & 32 & 1.582 & & \\
\hline
\end{tabular}

Berdasarkan hasil uji korelasi menggunakan teknik regresi sederhana diatas, didapatkan hasil yaitu $0,000(p<0,05)$. Maka dapat disimpulkan jika terdapat hubungan tingkat kejadian diabetes melitus terhadap kondisi hipertensi di Indonesia pada tahun 2018. Untuk mengetahui seberapa besar tingkat hubungan antara kejadian diabetes melitus terhadap kondisi hipertensi dapat dilihat pada tabel 6 sebagai berikut: 
Tabel 6. Hasil Uji Model Summary

\begin{tabular}{|l|r|r|r|}
\hline \multicolumn{4}{|c|}{ Model Summary } \\
\hline$R$ & $R$ Square & Adjusted R Square & Std. Error of the Estimate \\
\hline $.751^{\mathrm{a}}$ & .564 & .550 & 1.25767 \\
\hline
\end{tabular}

Berdasarkan hasil uji model summary diatas, didapatkan nilai koefisien determinasi ( $R$ Square) yaitu sebesar 0,564. Maka dapat disimpulkan jika tingkat hubungan antara kejadian diabetes melitus terhadap kondisi hipertensi di Indonesia pada tahun 2018 adalah sebesar 56,4\%.

\section{PEMBAHASAN}

Berdasarkan hasil data dari (Kemenkes, 2018) mengenai tingkat kondisi diabetes melitus pada masing-masing provinsi di dapat bahwa provinsi tertinggi yang memiliki tingkat kejadian diabetes melitus adalah Provinsi DKI Jakarta dengan angka 2,6\% dan provinsi yang memiliki tingkat kejadian diabetes melitus terendah adalah Provinsi Nusa Tengga Timur dengan angka 0,6\%. Berdasarkan hasil uji model summary, didapatkan nilai koefisien determinasi ( $R$ Square) yaitu sebesar 0,564 . Maka dari penelitian ini disimpulkan jika tingkat hubungan antara kejadian diabetes melitus terhadap kondisi hipertensi di Indonesia pada tahun 2018 adalah sebesar 56,4\%.

Provinsi DKI jakarta di sini memiliki tingkat tertinggi karena kurangnya asupan makanan yang kurang sehat, pola tidur yang kurang baik dan olahraga disini menyebabkan tubuh kurang seimbang (Hasfika et al., 2020). Karena di DKI jakarta itu sendiri merupakan kota besar dan dengan mayoritas penduduk yang aktivitasnya bekerja di sini menyebabkan tingginya kasus diabetes militus (Utami \& Kusumaningrum, 2021). Hal ini karena mayoritas memiliki kesibukankesibukan lainnya, sehingga mereka cenderung tidak memperhatikan penghitungan denyut nadi dan tidak memperhatikan intensitas olahraga yang dilakukan (Leggio et al., 2017). Kurang sehat di sini dapat diartikan seperti olahraga di malam hari kemudian program olahraga yang kurang tepat dan memaksakan tubuh yang lelah tetapi di paksa untuk berolahraga.

Diabetes mellitus merupakan salah satu penyakit metabolik ditandai dengan hiperglikemia yang disebabkan karena gangguan sekresi insulin, gangguan kerja insulin atau keduanya (Tatsumi \& Ohkubo, 2017). Faktor risiko yang yang dapat menimbulkan penyakit diabetes mellitus yaitu umur, jenis kelamin, bangsa dan etnik, faktor keturunan, riwayat melahirkan bayi dengan berat badan lahir lebih dari 4000 gram, riwayat menderita diabetes gestasional, obesitas, aktifitas fisik yang kurang, hipertensi, stres, pola makan, penyakit pada pankreas, dan Alkohol (Wu et al., 2017). Penyakit Diabetes Mellitus ini bisa diikuti dengan berbagai komplikasi, salah satunya Hipertensi (Lacey et al., 
JURNAL SPORTA SAINTIKA

P-ISSN 2505-5651

E-ISSN 2579-5910

2018). Selaras dengan penelitian (Gowshall \& Taylor-Robinson, 2018) resistensi insulin adalah kondisi dimana seseorang memiliki jumlah insulin yang cukup untuk merombak glukosa, namun tidak bekerja sebagaiman mestinya. Insulin, selain bekerja merubah glukosa menjadi glikogen dapat mengakibatkan peningkatan retensi natrium di ginjal dan mengakibatkan aktivitas sistem syaraf simpatik.

Sedangkan Provinsi Nusa Tengga Timur memiliki tingkat kejadian diabetes melitus terendah dengan angka $0,6 \%$. Karena di provinsi tersebut merupakan daerah pedesaan yang mayoritas terbanyak pada pekerja di NTT ini merupakan pekerja lapangan dengan aktifitas fisik yang tinggi (Osin et al., 2019). Dengan keseimbangan pola hidup yang berbeda disini dapat di simpulkan tingkat kejadian diabetes melitus terendah (Kjeldsen, 2018). Karena pekerjaan yang membutuhkan fisik maka dapat di artikan seperti sesorang yang sedang berolahraga yang dapat meningkatkan kebugaran jasmani (Pinto \& Martins, 2017). Olahraga ini mampu meningkatkan efisiensi dan fungsi metabolisme dalam tubuh (Emami et al., 2020). Olahraga juga sangat sesuai dilakukan karena dapat mempengaruhi semua otototot besar, pernapasan dan jantung.

Menurut (Geldsetzer et al., 2018), berbagai jenis olahraga untuk penderita diabetes dapat dijadikan bagian dari rutinitas, yaitu antara lain; 1) Latihan kekuatan tubuh, contoh strength training yang bisa di terapkan di rumah meliputi push up, sit up, squat, serta mengangkat barbel. Sebelum melakukan olahraga apapun, pastikan mengetahui stamina dan kesehatan terlebih dulu. Konsultasikan dengan dokter untuk mendapatkan rekomendasi pilihan olahraga yang aman dan sesuai dengan kondisi diabetes. 2) Bersepeda, bersepeda dapat memperkuat jantung dan meningkatkan fungsi paru-paru. Agar mendapatkan manfaat olahraga untuk penderita diabetes ini, perlu bersepeda selama 30 menit sebanyak 3-5 kali dalam seminggu. bisa bersepeda mengelilingi komplek perumahan, atau menggunakan sepeda statis yang digunakan di dalam ruangan. 3) Menari, cukup menggerakkan tubuh dan mengikuti irama musik selama 25 menit per sesi agar bisa merasakan berbagai manfaat menari tersebut. 4) Yoga, salah satu jenis olahraga untuk penderita diabetes lainnya adalah yoga, kondisi positif ini bisa membantu dalam menjaga kestabilan kadar gula darah. 5) Berenang, guna mendapatkan manfaat berenang bagi penderita diabetes, dianjurkan untuk melakukan jenis olahraga kardio ini sebanyak tiga kali dalam seminggu. Pada tahap awal, bisa berenang selama 10 menit tanpa henti. Setelah terbiasa, dapat meningkatkan durasi berenang secara bertahap hingga 30 menit per sesi. Meski demikian, tetap perlu berhati-hati ketika berenang. Misalnya, memerhatikan keselamatan diri agar tidak tergelincir atau terjatuh di tepi kolam renang. 6) Tai chi, berakar dari seni bela diri, tai chi ternyata bisa pula bermanfaat sebagai olahraga untuk penderita diabetes. 
JURNAL SPORTA SAINTIKA

P-ISSN 2505-5651

E-ISSN 2579-5910

Hipertensi merupakan masalah kesehatan masyarakat yang terjadi di negara maju maupun negara berkembang. Hipertensi merupakan suatu keadaan dimana tidak ada gejala yang yang ditimbulkan sebelumnya. Hipertensi merupakan salah satu penyakit degeneratif yang harus diwaspadai. Hipertensi yaitu penyakit yang menyebabkan angka kematian terbesar nomor tiga di Indonesia setalah stroke (15,4\%) dan tuberculosis (7,5\%) (Ismanto \& Rahmawati, 2018), Jenis olahraga yang efektif menurunkan tekanan darah adalah olahraga aerobik dengan intensitas sedang (70-80\%). Frekuensi latihannya 3-5 kali seminggu, dengan lama latihan 20-60 menit sekali latihan. Olahraga seperti jalan kaki atau jogging yang dilakukan selama 16 minggu akan mengurangi kadar hormon norepinerlin (noradrenalin) dalam tubuh, yakni zat yang mengeluarkan sistem saraf yang dapat menaikan tekanan darah (Prasetyo, 2017)

\section{KESIMPULAN}

Indonesia merupakan negara termasuk ke dalam kelompok negara berkembang, hal ini berimplikasi pada tingkat pendidikan, sosial, ekonomi maupun kesehatan. pada bidang kesehatan mereplikasi pada bagaimana peta persebaran tingkat berbagai penyakit yang menyerang masyarkat di Indonesia. Adapun penyakit yang umumnya ada pada masyarkat Indonesia berdasrkan data Kemenkes 2018 adalah penyakit diabetes melitus dan hipertensi atau lebih dikenal denan penyakit darah tinggi. Adapun tujuan dari penelitian ini, untuk mengetahui bagaimana korelasi dari kedua penyakit tersebut. Adapun hasil penelitian ini dapat disimpulkan bahwa terdapat hubungan yang bermakna antara tingkat kejadian diabetes melitus terhadap kondisi hipertensi di Indonesia pada tahun 2018 dengan tingkat hubungan sebesar 56,4\%. Melalui temuan tersebut diharapkan dapat menambah informasi pada pemerintah dan terkhusus masyarkat di Indonesia, supaya dapat lebih menjaga pola makan, kebiasaan dan rutin menjaga kesehatan melalui olahraga. Agar terhindar dari penyakit diabetes melitus yang memiliki korelasi pada penyakit hipertensi.

\section{DAFTAR PUSTAKA}

Betteng, R. (2014). Analisis faktor resiko penyebab terjadinya Diabetes Melitus tipe 2 pada wanita usia produktif Dipuskesmas Wawonasa. EBiomedik, 2(2).

Emami, A., Javanmardi, F., Pirbonyeh, N., \& Akbari, A. (2020). Prevalence of underlying diseases in hospitalized patients with COVID-19: a systematic review and meta-analysis. Archives of Academic Emergency Medicine, 8(1).

Fransisca, K. (2018). Awas pankreas rusak penyebab diabetes. Jakarta: Cerdas Sehat.

Geldsetzer, P., Manne-Goehler, J., Theilmann, M., Davies, J. I., Awasthi, A., Vollmer, S., Jaacks, L. 
JURNAL SPORTA SAINTIKA

P-ISSN 2505-5651

E-ISSN 2579-5910

M., Bärnighausen, T., \& Atun, R. (2018). Diabetes and hypertension in India: a nationally representative study of 1.3 million adults. JAMA Internal Medicine, 178(3), 363-372.

Gowshall, M., \& Taylor-Robinson, S. D. (2018). The increasing prevalence of non-communicable diseases in low-middle income countries: the view from Malawi. International Journal of General Medicine, 11, 255.

Hasfika, I., Erawati, S., \& Sitorus, F. E. (2020). Pengaruh Senam Prolanis Terhadap Pengendalian Kadar Glukosa Darah dan Tekanan Darah Pada Pasien Diabetes Melitus Tipe II dan Hipertensi. BEST Journal (Biology Education, Sains and Technology), 3(2), 184-190.

Ismanto, I., \& Rahmawati, T. (2018). Hubungan Olahraga terhadap tekanan darah penderita hipertensi rawat jalan di rumah sakit PKU Muhammadiyah Surakarta. Profesi: Media Publikasi Penelitian, 10(01), 162020.

Kemenkes. (2018). Laporan Nasional Riskesdas 2018.

Kjeldsen, S. E. (2018). Hypertension and cardiovascular risk: general aspects. Pharmacological Research, 129, 95-99.

Lacey, B., Lewington, S., Clarke, R., Kong, X. L., Chen, Y., Guo, Y., Yang, L., Bennett, D., Bragg, F., \& Bian, Z. (2018). Age-specific association between blood pressure and vascular and nonvascular chronic diseases in 0.5 million adults in China: a prospective cohort study. The Lancet Global Health, 6(6), e641-e649.

Leggio, M., Lombardi, M., Caldarone, E., Severi, P., D’emidio, S., Armeni, M., Bravi, V., Bendini, M. G., \& Mazza, A. (2017). The relationship between obesity and hypertension: an updated comprehensive overview on vicious twins. Hypertension Research, 40(12), 947-963.

Nindyasari, N. D. (2010). Perbedaan tingkat kecemasan pada penderita diabetes mellitus (dm) tipe $i$ dengan diabetes mellitus ( $\mathrm{dm}$ ) tipe II.

Nugroho, A. E. (2018). Hewan percobaan diabetes mellitus: patologi dan mekanisme aksi diabetogenik. Biodiversitas, 7(4), 378-382.

Osin, R. F., Kusuma, I. R. W., \& Suryawati, D. A. (2019). Strategi Pengembangan Objek Wisata Kampung Tradisional Bena Kabupaten Ngada-Flores Nusa Tenggara Timur (NTT). Jurnal Ekonomi Dan Pariwisata, 14(1).

Pane, H. W., Tasnim, T., Sulfianti, S., Hasnidar, H., Puspita, R., Hastuti, P., Apriza, A., Pattola, P., Sianturi, E., \& Rifai, A. (2020). Gizi dan Kesehatan. Yayasan Kita Menulis.

Pinto, I. C., \& Martins, D. (2017). Prevalence and risk factors of arterial hypertension: A literature review. Journal of Cardiovascular Medicine and Therapeutics, 1(2), 1-7.

Prasetyo, Y. (2017). Olahraga bagi penderita hipertensi. Medikora, 1. 
JURNAL SPORTA SAINTIKA

P-ISSN 2505-5651

E-ISSN 2579-5910

Pratita, N. D. (2013). Hubungan dukungan pasangan dan health locus of control dengan kepatuhan dalam menjalani proses pengobatan pada penderita diabetes mellitus tipe-2. Calyptra, 1(1), 124.

Saragih, H. (2018). Hubungan antara Diabetes Mellitus dengan Hipertensi pada Pralansia dan Lansia di Puskesmas Rambung Kota Tebing Tinggi.

Setiawan, H., Suhanda, Sopatilah, E., Rahmat, G., Wijaya, D. D., \& Ariyanto, H. (2018). Hubungan Tingkat Pengetahuan Penderita Diabetes Mellitus 2. Urecol, 241-248.

Sumampouw, O. J. (2017). Pemberantasan Penyakit Menular. Deepublish.

Suoth, M., Bidjuni, H., \& Malara, R. (2014). Hubungan gaya hidup dengan kejadian hipertensi di puskesmas kolongan kecamatan kalawat kabupaten minahasa utara. Jurnal Keperawatan, 2(1).

Tatsumi, Y., \& Ohkubo, T. (2017). Hypertension with diabetes mellitus: significance from an epidemiological perspective for Japanese. Hypertension Research, 40(9), 795-806.

Thompson, P., \& Bhushan, A. (2017). $\beta$ Cells led astray by transcription factors and the company they keep. Journal of Clinical Investigation, 127(1), 94-97. https://doi.org/10.1172/JCl91304

Trisnawati, S. (2018). Faktor risiko diabetes mellitus tipe 2 pasien rawat jalan di Puskesmas Wilayah Kecamatan Denpasar Selatan. Public Health and Preventive Medicine Archive, 1(1), 21527.

Utami, N. D., \& Kusumaningrum, N. S. D. (2021). The Effect of Physical Activity on Diabetes Mellitus Patients with Hypertension. KnE Life Sciences, 22-31.

Wu, J., Xun, P., Tang, Q., Cai, W., \& He, K. (2017). Circulating magnesium levels and incidence of coronary heart diseases, hypertension, and type 2 diabetes mellitus: a meta-analysis of prospective cohort studies. Nutrition Journal, 16(1), 1-13.

Yosmar, R., Almasdy, D., \& Rahma, F. (2018). Survei risiko penyakit diabetes melitus terhadap masyarakat Kota Padang. Jurnal Sains Farmasi \& Klinis, 5(2), 134-141. 